\title{
Efektivitas HE4 sebagai Metode Skrining Terbaru untuk Diagnosis Dini Kanker Ovarium
}

\author{
Amru Sofian ${ }^{1}$, Hendra Perkasa ${ }^{2}$, Ega Rahman Evsya², Riyan M. Darundryo²
}

\begin{abstract}
The tumor marker CA125 is one of the currently used biomarkers to detect ovarian cancer. The tumor marker CA125 also elevated in other diseases. Human epididymis protein 4 is used as a new biomarker for early detection of ovarian cancer. Human epididymis protein 4 is increased in almost all patients with ovarian cancer and increased only slightly at a fraction of other diseases. Human epididymis protein 4 has a better effectiveness in detecting ovarian cancer when combined with CA125. From the study of literature found that the combination of HE4 and CA125 had a specificity of $96.3 \%$ and $92.9 \%$ sensitivity.
\end{abstract}

Keywords: Ovarian cancer, effectiveness, CA125, HE4

Kanker ovarium adalah kanker yang mengenai satu atau kedua ovarium yang berfungsi menghasilkan sel telur untuk reproduksi. ${ }^{1,2}$ Penyebab dari kanker ovarium ini masih belum diketahui secara pasti. ${ }^{3}$ Banyak faktor risiko yang berperan dalam meningkatnya prevalensi kanker ovarium yaitu usia (perimenopause dan postmenopause) ${ }^{4}$, riwayat keluarga ${ }^{5}$, genetik ${ }^{3}$ (BRCA1 dan BRCA2) ${ }^{6,7}$ dan faktor reproduksi lainnya.

Penderita kanker ovarium umumnya didiagnosis terlambat, karena belum adanya metode deteksi dini yang akurat untuk kanker ovarium. Hanya $25 \%$ dari wanita penderita kanker ovarium yang terdiagnosis pada stadium awal karena tidak spesifiknya gejala dan tanda, sulitnya mengakses ovarium dengan pemeriksaan fisik dan rendahnya pengetahuan dari dokter umum sehingga pada saat merujuk ke dokter spesialis onkologi kandungan sudah pada stadium lanjut. ${ }^{4,8,9}$

Selain itu, penegakan diagnosis kanker ovarium yang sulit seringkali membingungkan para tenaga medis dalam menentukan tindakan yang akan

\footnotetext{
Bagian Obstetri dan Gynecology Fakultas Kedokteran Universitas Riau. Jl. Diponegoro No. 1, Pekanbaru. Email: pekanbaru cancercenter@yahoo.com

2 Penulis korespondensi: Mahasiswa Fakultas Kedokteran Universitas Riau
}

dilakukan dan dokter yang berkompetensi dalam melakukan tindakan tersebut. Kesalahan dalam menentukan ganas atau tidaknya suatu tumor dapat menyebabkan pasien mengalami undertreatment, yaitu pasien dengan tumor ganas yang seharusnya ditangani oleh dokter onkologi kandungan tetapi justru ditangani oleh dokter bukan onkolog. Hal ini disebabkan oleh metode skrining yang kurang sensitif dan spesifik dalam menentukan ganas atau tidaknya suatu tumor. ${ }^{10}$

Saat ini belum ada metode skrining yang spesifik untuk kanker ovarium. Walaupun demikian saat ini sedang dikembangkan suatu metode untuk deteksi dini kanker ovarium yang asimptomatik. Pemeriksaan fisik, pemeriksaan pelvis, riwayat keluarga dan gejala sangat penting diperhatikan. ${ }^{4}$

Beberapa tahun belakangan ini beberapa petanda tumor telah terdeteksi dalam darah pasien kanker ovarium yaitu BRCA-1 dan BRCA-2, Carcinoembrionic antigen (CEA), alpha feto protein (AFP) dan human chorionic gonadotrophin (hCG) tetapi sensitivitas dan spesifisitas petanda tersebut dalam memprediksi kanker ovarium tidak lebih baik dari pada CA125. Walaupun secara umum CA125 memiliki sensitivitas yang tinggi, penggunaan klinis CA125 sebagai petanda untuk menegakkan diagnosis kanker ovarium masih sangat terbatas. Hal 
ini dikarenakan CA125 juga meningkat pada wanita dengan kanker kolon, kanker payudara, kanker rahim, tumor jinak genital, menstruasi, kehamilan, endometriosis dan penyakit lainnya yang berhubungan dengan reaksi inflamasi di pleura, perikardium, dan peritoneum. ${ }^{4}$

Penelitian Kim YM et al (2011) telah menghasilkan penemuan sebuah biomarker baru yang dikenal dengan nama human epididymis protein 4 (HE4). Human epididymis protein 4 (HE4) ditemukan di epitel bagian distal dari epididimis yang diduga sebagai protease inhibitor dalam proses pematangan sperma. HE4 juga dikenal dengan nama WAP four-disulfide core domain protein 2 (WFDC2) karena mengandung 2 domain protein asam dan satu ikatan inti 4 disulfida yang terbentuk dari 8 residu sistein. ${ }^{4}$ Berangkat dari hal diatas, penulis tertarik untuk mengamati potensi HE4 sebagai biomarker baru dalam skrining untuk deteksi dini kanker ovarium.

\section{Efektifitas HE4 sebagai Metode Skrining Terbaru untuk Diagnosis Dini Kanker Ovarium}

Gen human epididymis protein 4 (HE4) merupakan gen yang diekpresikan paling berlebihan oleh kanker ovarium. Human epididymis protein 4 (HE4) dideskripsikan sebagai gen spesifik di epitel distal epididimis menggunakan analisis northern blot dan transkrip hibridisasi in situ. Gen HE4 berada pada kromosom manusia 20q12-13. Secara signifikan, studi hibridisasi dengan membandingkan genom telah menunjukkan bahwa 20q13 merupakan salah satu daerah kromosom yang paling sering di invasi oleh karsinoma ovarium. Namun, kepastian interpretasi dari ekspresi protein HE4 pada kanker ovarium tipe epithelial dengan kanker pada organ lain maupun jaringan normal masih belum diketahui. ${ }^{11}$

Dari penelitian Anastasi E, et al., 2009 diteliti kadar CA125 dan HE4 pada serum sampel yang dikumpulkan dari 267 pasien yang dicurigai menderita keganasan berdasarkan hasil labor. ${ }^{12}$

Tabel 4.1 Sebaran kadar HE4 positif yang dibagi dalam kuartil pada pasien yang diamati ${ }^{12}$

\begin{tabular}{lcccc}
\hline & Kuartil & Kuartil & Kuartil & Kuartil \\
& I & II & III & IV \\
& $(150-249)$ & $(150-249)$ & $(150-249)$ & $(150-249)$ \\
\hline Kanker ovarium & 11 & 4 & 3 & 13 \\
Kanker kolon & - & - & - & - \\
Kanker payudara & 3 & - & - & - \\
Kanker serviks & 2 & - & - & - \\
Kanker ovarium non keganasan & - & - & - & - \\
Penyakit non keganasan lainnya & - & - & - & - \\
\hline
\end{tabular}

Dari Tabel 4.1 dapat dilihat bahwa dari 32 orang penderita kanker ovarium ditemukan 31 orang memiliki kadar HE4 diatas batas normal (150pmol/ L). Dapat disimpulkan bahwa sensitivitas HE4 terhadap kanker ovarium sebesar 96,7\% (31/32). Sedangkan pada keadaan non-kanker ataupun keganasan selain kanker ovarium, peningkatan serum HE4 hanya ditemukan sebesar $3,7 \%(5 / 163) .{ }^{12}$

Tabel 4.2 Sebaran kadar CA 125 positif yang dibagi dalam kuartil pada pasien yang diamati ${ }^{12}$

\begin{tabular}{|c|c|c|c|c|}
\hline & $\begin{array}{c}\text { Kuartil } \\
I \\
(150-249)\end{array}$ & $\begin{array}{c}\text { Kuattil } \\
\text { II } \\
(150-249) \\
\end{array}$ & $\begin{array}{c}\text { Kuartil } \\
\text { III } \\
(150-249) \\
\end{array}$ & $\begin{array}{c}\text { Kuartil } \\
\Gamma \\
(150-249) \\
\end{array}$ \\
\hline Kanker ovarium & 10 & 3 & 3 & 12 \\
\hline Kanker kolon & 2 & - & 1 & - \\
\hline Kanker payudara & 7 & 1 & - & - \\
\hline Kanker serviks & 2 & 2 & - & - \\
\hline Kanker ovarium non keganasan & 10 & - & - & - \\
\hline Peny akit non keganasan lainnya & 7 & - & 1 & 1 \\
\hline
\end{tabular}


Dari Tabel 4.2 dapat dilihat bahwa dari 32 orang penderita kanker ovarium ditemukan 28 orang memiliki kadar CA125 diatas batas normal (35 unit/ $\mathrm{ml})$. Dapat disimpulkan bahwa sensitivitas CA125 terhadap kanker ovarium sebesar 87,5\% (28/32). Sedangkan peningkatan serum CA125 pada keadaan non-kanker ataupun keganasan selain kanker ovarium sebesar $21 \%(34 / 163){ }^{12}$

Pada penelitian ini HE4 meningkat pada hampir semua penderita kanker ovarium dan hanya pada sebagian kecil pada penyakit lain. Pada penyakit selain kanker ovarium, Peningkatan HE4 yang terjadi tidak terlalu signifikan yaitu hanya berada pada kuartil I (Tabel 4.1). Selain itu juga dapat disimpulkan bahwa CA125 tidak cukup spesifik di banding HE4 dalam menentukan seseorang terkena kanker ovarium atau tidak, karena peningkatan kadar CA125 ditemukan di lebih banyak sampel dan kadarnya juga menyebar di Kuartil I-IV (Tabel 4.2). ${ }^{12}$

Penelitian juga dilakukan pada 224 orang subjek kontrol sehat yang berkunjung ke Health Promotion Center of Inje University Seoul Paik Hospital. ${ }^{11}$

Tabel. 4.3 Serum HE4 dan CA125 pada setiap bagian dari populasi yang diteliti ${ }^{11}$

\begin{tabular}{|c|c|c|c|c|c|}
\hline \multirow{2}{*}{ Karakteristik } & \multirow{2}{*}{ n $(\%)$} & \multicolumn{2}{|c|}{ HE. p. mol/L } & \multicolumn{2}{|c|}{ CA 125. U.ml } \\
\hline & & Median & Range & Median & Range \\
\hline Jumlah & $383(100,0)$ & 35,9 & $13,9-9215$ & 14,4 & $33-12,690$ \\
\hline \multicolumn{6}{|l|}{ Status Penyakit } \\
\hline $\begin{array}{l}\text { Kontrol Sehat } \\
\text { Penyakit non }\end{array}$ & $224(58,5)$ & 35,3 & $13,9-88,6$ & 11,5 & $3,3-38,2$ \\
\hline keganasan Ovarium & $81(21,1)$ & 29,8 & $16,5-57,5$ & 21,3 & $4,6-272,5$ \\
\hline Kanker Ovarium & $78(20,4)$ & 80,0 & $25,4-92,15$ & 216,3 & $9-12,690$ \\
\hline $\mathrm{p}-$ Value & & 0,0 & & 0,0 & \\
\hline \multicolumn{6}{|l|}{ Usia } \\
\hline$<49$ & $136(48,6)$ & 32,7 & $18-1255,7$ & 17,3 & $4,6-66,01$ \\
\hline$\geq 49$ & $197(51,4)$ & 39,5 & $13,9-92,15$ & 11,4 & $3,3-12,690$ \\
\hline $\mathrm{p}-$ Value & & 0,0 & & 0,0 & \\
\hline \multicolumn{6}{|l|}{$\begin{array}{l}\text { Menopause pada } \\
\text { kontrol sehat }\end{array}$} \\
\hline premenopausal & $102(45,5)$ & 33,3 & $22,5-75,9$ & 14,1 & $4,8-38,2$ \\
\hline postmenopausal & $122(54,5)$ & 37,9 & $13,9-88,6$ & 9,7 & $3,3-29,7$ \\
\hline $\mathrm{p}$-Value & & 0,0 & & 0,0 & \\
\hline \multicolumn{6}{|l|}{$\begin{array}{l}\text { Menopause pada } \\
\text { penyakit non- } \\
\text { keganasan }\end{array}$} \\
\hline premenopausal & $71(87,7)$ & 29,7 & $18-57,5$ & 30,0 & $4,6-272,5$ \\
\hline postmenopausal & $10(12,3)$ & 30,7 & $16,5-55,8$ & 9,5 & $5,3-24$ \\
\hline $\mathrm{p}$-Value & & 0,7 & & 0,0 & \\
\hline $\begin{array}{l}\text { Menopause } \\
\text { padakanker ovarium }\end{array}$ & & & & & \\
\hline premenopausal & $37(47,4)$ & 66,6 & $25,4-1255,7$ & 219,3 & $9-12,690$ \\
\hline postmenopausal & $41(52,6)$ & 86,7 & $33,6-92,15$ & 186,9 & $10,4-343,6$ \\
\hline
\end{tabular}

Dari hasil penelitian ini di dapatkan bahwa sensitifitas HE4 dalam mengidentifikasi kanker ovarium pada wanita dengan massa adneksa sebesar $73,1 \%$ dengan spesifisitas $95 \%$ dan sensitifitas
71,8\% pada spesifisitas $98 \%$. Penelitian ini juga mendukung bahwa serum HE4 lebih baik dalam membedakan antara kanker ovarium dan tumor jinak. Sedangkan pada penggunaan kombinasi HE4 
dan CA125 secara bersamaan akan meningkatkan sensitivitas. ${ }^{11}$

Penelitian lain dilakukan oleh K Huhtingen, et al., 2005-2007 di dua rumah sakit pusat Universitas di Finlandia. Mereka meneliti kadar HE4 dan CA125 dalam serum 129 penderita endometriosis yang 69 diantaranya menderita endometrioma ovarium. Data yang didapat akan dibandingkan dengan hasil pemeriksaan yang sama pada 14 penderita kanker ovarium, 16 penderita kanker endometrium, dan 66 wanita yang melakukan kontrol kesehatan (Tabel 4.4). ${ }^{13}$

Tabel 4.4 Gambaran pasien dengan analisis serum HE4 dan CA125 $5^{13}$

\begin{tabular}{lccccc}
\hline \multirow{2}{*}{ Diagnosis } & \multirow{n}{*}{} & \multicolumn{5}{c}{ Classification (ASRM) Stage (FICHO) } \\
\cline { 3 - 6 } & & I & II & III & IV \\
\hline Pasien Kontrol & 66 & & & & \\
Kesel uruhan Endometrium & 129 & 16 & 17 & 33 & 63 \\
$\quad$ Ovarium Endometrioma & 69 & - & - & 24 & 45 \\
Kanker Endometrium & 16 & 13 & 1 & 2 & - \\
Kanker Ovarium & 14 & 4 & 1 & 7 & 2 \\
$\quad$ Serous & 7 & - & - & 6 & 1 \\
Mucinous & 3 & 3 & - & - & - \\
Clear Cell & 2 & - & 1 & 1 & - \\
$\quad$ Endometrioid & 1 & 1 & - & - & - \\
Small Cell & 1 & - & - & - & 1 \\
Total & 225 & & & &
\end{tabular}

Tabel 4.5a Konsentrasi serum HE4 pada pasien endometriosis, kanker endometrium, dan kanker ovarium ${ }^{13}$

\begin{tabular}{|c|c|c|c|c|c|c|}
\hline \multirow{2}{*}{ Diagnosis } & \multirow{2}{*}{$\mathbf{n}$} & \multicolumn{5}{|c|}{ HE4 (pM) } \\
\hline & & Mean & s.d & Median & Range & $p$ \\
\hline Pasien Kontrol & 66 & 40,5 & 10,3 & 38,6 & $(27,0-80,7)$ & - \\
\hline Endometriosis & 129 & 45,5 & 13,4 & 43,5 & $(15,2-111,0)$ & - \\
\hline Stage 1 & 16 & 46,7 & 11,4 & 42,9 & $(35,1-80,9)$ & 0,96192 \\
\hline Stage 2 & 17 & 44,9 & 13,1 & 43,9 & $(28,7-72,0)$ & 0,99718 \\
\hline Stage 3 & 33 & 43,2 & 11,4 & 43,4 & $(15,2-68,0)$ & - \\
\hline Stage 3 w/o OvEndo & 9 & 43,9 & 10,1 & 43,8 & $(32,6-61,9)$ & 0,99971 \\
\hline Stage 4 & 63 & 46,5 & 15,0 & 44,0 & $(26,8-111,0)$ & - \\
\hline Stage 4 w/o OvEndo & 18 & 43,5 & 12,1 & 40,9 & $(27,4-64,5)$ & 0,99973 \\
\hline Endometriosi Ovarium & 69 & 46,0 & 14,9 & 44,0 & $(15,2-111,0)$ & 0,89441 \\
\hline Kanker Endometrium & 16 & 99,2 & 76,4 & 73,3 & $(26,5-330,5)$ & 0,00001 \\
\hline Kanker Ovarium & 14 & 1125,4 & 2670,0 & 268,3 & $(46,5-10250,0)$ & 0,00000 \\
\hline Serous & 7 & 2031,1 & 3669,1 & 562,5 & $(46,5-10250,0)$ & - \\
\hline Mrucinous & 3 & 202,6 & 189,7 & 113,0 & $(74,4-420,5)$ & - \\
\hline Clear Cell & 2 & 397,6 & 477,2 & 397,6 & $(60,1-735,0)$ & - \\
\hline Endometrioid & 1 & 70,0 & - & 70,0 & - & - \\
\hline Small cell & 1 & 64,1 & - & 64,1 & - & - \\
\hline
\end{tabular}


Tabel 4.5b Konsentrasi serum CA125 pada pasien endometriosis, kanker endometrium, dan kanker ovarium ${ }^{13}$

\begin{tabular}{lcccccc}
\hline \multicolumn{1}{c}{ Diagnosis } & $\mathbf{n}$ & Mean & s.d & Median & Range & p \\
\hline Pasien Kontrol & 66 & 8,9 & 6,2 & 6,7 & $(2,2-31,2)$ & - \\
& & & & & & \\
Endometriosis & 129 & 35,8 & 36,0 & 25,3 & $(0,8-182,0)$ & - \\
$\quad$ Stage 1 & 16 & 15,6 & 9,8 & 11,5 & $(5,1-44,4)$ & $0,3456,0$ \\
$\quad$ Stage 2 & 17 & 21,4 & 18,4 & 14,8 & $(3,5-70,5)$ & 0,09637 \\
Stage 3 & 33 & 25,1 & 22,7 & 14,8 & $(0,9-79,0)$ & - \\
$\quad$ Stage 3 wio OvEndo & 9 & 23,3 & 25,4 & 13,4 & $(2,6-79,0)$ & 0,58802 \\
$\quad$ Stage 4 & 63 & 50,4 & 43,1 & 36,7 & $(0,8-182,0)$ & - \\
$\quad$ Stage 4 w/o OvEndo & 18 & 40,8 & 30,9 & 32,1 & $(0,8-127,0)$ & 0,00001 \\
Endometriosi Ovarium & 69 & 44,3 & 42,1 & 33,7 & $(0,9-182,0)$ & 0,00000 \\
& & & & & & \\
Kanker Endometrium & 16 & 22,0 & 23,0 & 15,5 & $(9,6-106,0)$ & 0,02915 \\
& & & & & & \\
Kanker Ovarium & 14 & 1117,1 & 1971,0 & 240,0 & $(6,6-6890,0)$ & 0,00000 \\
$\quad$ Serous & 7 & 1938,7 & 2588,7 & 341,0 & $(28,9-6890,0)$ & - \\
$\quad$ Mucinous & 3 & 201,5 & 186,0 & 221,0 & $(6,6-377,0)$ & - \\
$\quad$ Clear Cell & 2 & 674,5 & 587,6 & 674,5 & $(259-1090,0)$ & - \\
Endometrioid & 1 & 97,0 & - & 97 & - & - \\
Small Cell & 1 & 17,8 & - & 17,8 & - & - \\
\hline
\end{tabular}

Dari hasil penelitian ini disimpulkan bahwa untuk membedakan antara pasien kontrol dan penderita kanker ovarium, kombinasi HE4 dan CA125 lebih baik daripada penggunaan tunggal HE4 atau CA125 dengan spesifisitas $96,3 \%$ dan sensitivitas $92,9 \%$. Kombinasi ini memiliki spesifisitas $94,0 \%$ dan sensitivitas $78,6 \%$ dalam membedakan kanker ovarium dengan endometriosis ovarium. Dan yang terakhir, kombinasi HE4 dan CA125 memiliki spesifisitas $81,9 \%$ dalam membedakan pasien normal, penderita kanker ovarium, dan penderita endometriosis ovarium (Tabel 4.5a-b). ${ }^{13}$

Andersen, et al. di Fred Hutchinson Cancer Research Center mengevaluasi metode diagnosis kanker ovarium terbaru dengan mengkombinasikan Symptom Index (SI) dengan uji serum HE4 atau CA125 untuk meningkatkan efektifitas dalam memprediksi kanker ovarium. Penelitian ini menggunakan studi kasus-kontrol prospektif yang melibatkan 74 wanita dengan kanker ovarium dan 137 lainnya sehat. ${ }^{14}$
Pada studi ini, HE4 lebih baik dari CA125 dengan kombinasinya terhadap SI (100\% vs 78,6\% sensitivitas dengan spesifitas $95 \%$ masing-masing HE4 dan CA125). Temuan ini membuktikan bahwa HE4 mengungguli CA125 sebagai first-line screening karena sensitivitasnya yang tinggi. Penggunaan SI bersama-sama dengan HE4 dan CA125 menghasilkan sensitivitas dan spesifitas yang nyaris sempurna $(83,8 \%$ sensitivitas dan $98,5 \%$ spesitivitas). ${ }^{14}$

\section{KESIMPULAN}

Human epididymis protein 4 (HE4) adalah suatu penanda tumor terbaru dalam skrining kanker ovarium yang diekspresikan sebagai gen spesifik di epitel distal epididimis menggunakan analisa northen blot dan transkrip hibridisasi in situ. Human epididymis protein 4 (HE4) meningkat pada hampir semua penderita kanker ovarium dan hanya pada sebagian kecil pada penyakit lain dengan peningkatan yang tidak terlalu signifikan. Efektifitas 
HE4 sebagai metode skrining terbaru untuk diagnosis dini kanker ovarium akan lebih baik apabila dikombinasikan dengan CA125. Kombinasi HE4 dan CA125 memiliki spesifisitas 96,3\% dan sensitivitas $92,9 \%$ yang lebih baik dari pada penggunaan HE4 atau CA125 secara tunggal.

\section{DAFTAR PUSTAKA}

1. American Cancer Society. Ovarian Cancer. (dikutip 30 Juli 2011). Available from: URL: HYPERLINK http://www.cancer.org

2. Varmus H. Ovarian Cancer. National cancer Institute. (dikutip 22 Agustus 2011). Available from: URL: HYPERLINK http:// www. cancer.gov/cancertopics/types/ovarian

3. Helm CW. Ovarian cancer 2010. (dikutip 31 Juli 2011). Available from: URL: HYPERLINK http://emedicine.medscape.com/article/265651overview

4. Ahmed N, Abubaker K, Findlay J, Quinn M. Epithelial mesenchymal transition and cancer stem cell-like pheno-types facilitate chemoresistance in recurrent ovarian cancer. Current Cancer Drug Targets. 2010; 10: p26878.

5. The Cancer Council New South Wales. Understanding ovarian cancer: a guide for women with cancer, their families and friends.(dikutip 30 Juli 2011). Available from: URL: HYPERLINK http://www. cancercouncil. $\underline{\text { com.au }}$

6. Ramus SJ, Kartsonaki C, Gayther SA, Pharoah PD, Sinilnikova OM, Beesley J, et al. Genetic variation at 9p22.2 and ovarian cancer risk for BRCA1 and BRCA2 mutation carriers. J Natl Cancer Inst. Jan 19 2011;103(2): p105-16.
7. Pruthi S, Gostout BS, Lindor NM. Identification and management of women with BRCA mutations or hereditary predisposition for breast and ovarian cancer. Mayo Clin Proc. 2010;85(12): p1111-20.

8. Gladstone CQ. Screening for ovarian cancer. Ontario. 1992; p869-81.

9. Rein BJD, Gupta S, Dada R, Safi J, Michener C, Agarwal A. Potential markers for detection and monitoring of ovarian cancer. Journal of Oncology. 2011; p1-17.

10.The Cancer Council New South Wales. Understanding ovarian cancer: a guide for women with cancer, their families and friends. (dikutip 30 Juli 2011). Available from: URL: HYPERLINK. http:// www. cancercouncil. com.au.

11. Kim YM, Whang DH, Park J, Kim SH, Lee SH, Park HA, et.al . Evaluation of the accuracy of serum human epididymis protein 4 in combination with CA125 for detecting ovarian cancer: a prospective case-control study in a Korean population. Clin Chem Lab Med. 2011; 49(3): 527-34.

12. Anastasi E, Marchei GG, Viggiani V, Gennarini G, Frati L, Reale MG. HE4: a new potential early biomarker for the recurrence of ovarian cancer. Tumor Biol. 2010; 31:113-9.

13. Huhtinen K, Suvitie P, Hiissa J, Junnila J, Huvila J, Kujari H, et.al. Serum HE4 concentration differentiates malignant ovarian tumours from ovarian endometriotic cysts. British Journal of Cancer. 2009; 100: 1315-9.

14.Andersen M, Goff B, Lowe K, Scholler N, Bergan L, Drescher C, et al. Use of a symptom index, CA125 and HE4 to predict ovarian cancer. Gynecol Oncol. 2010 March; 116(3): 378. 